\title{
ACADEMIC ACHIEVEMENT IN ENVIRONMENTAL SCIENCE OF B.ED. STUDENTS
}

\author{
${ }^{1}$ Mrs. V.Gnanaselvi \\ ${ }^{1}$.Ph.D Research Scholar, Bharathidasan University, Trichy. \\ ${ }^{2}$ Dr. Edward William Benjamin \\ ${ }^{2}$.Research Supervisor, Bharathidasan University, Trichy.
}

Article DOI URL: https://doi.org/10.36713/epra6663

Article DOI: 10.36713/epra6663

\begin{abstract}
The role of Environmental education is perceived as one that would generate awareness and provide opportunities to gain knowledge, attitudes and skills which are required to protect and improve the environment. This study examines Academic Achievement in Environmental Science of B.Ed.students, with reference to their Gender, Stream of Subjects and Qualification. The Academic Achievement in environmental science was collected from the respective colleges. The results of the present study reflect that there is no significant relationship with respect to Gender, there exist significant relationship in Academic Achievement of Environmental science between Arts and Science students and Undergraduate and Postgraduates student.
\end{abstract}

KEYWORDS: Environmental science, Academic achievement, B.Ed. students.

\section{INTRODUCTION}

As per the orders of the Honorable Supreme court, the subject of Environmental Studies was introduced as a compulsory subject in 2003 at the undergraduate level in all the streams. Supreme Court directed the Universities to include Environmental Studies in their curricula.

The objective behind the order was to raise the environmental conscience and consciousness among the young citizens so that they may realize the importance of environment for human wellbeing. Sustainability issues related to environmental management are more frequently discussed and corporations are engaging more with sustainability matters now. Due to this, global environmental problems such as decline in biodiversity, environmental pollution, waste generation and climate change have become very important. It is next to impossible for Indian companies to ignore the environmental consequences of their actions. In view of this, the syllabus was well framed and included all the pertinent issues, which are quite relevant in the present context.

The importance of having a environmental science curriculum in colleges.

- The subject gives a direct contact with nature and the knowledge of it.

- Environmental Science encompasses many other science domains.

- Environmental Science encourages collaborative studies.

- Conscientizes students to the problems of the planet earth.

\section{Definition of the terms}

Environmental science

Environmental science is an interdisciplinary academic field that integrates physical, biological and 


\section{EPRA International Journal of Research and Development (IJRD)}

information sciences (including ecology, biology, physics, chemistry, plant science, zoology, mineralogy, oceanography, limnology, soil science, geology and physical geography, and atmospheric science) to the study of the environment, and the solution of environmental problems.

\section{Academic achievement}

Academic achievement or academic performance is the extent to which a student, teacher or institution has attained their short or long-term educational goals.

\section{REVIEW OF RELATED LITERATURE}

1.LincolnFok (03 Mar 2016), a study on Students' academic performance in environmental studies: an empirical study of different groups of secondary school graduates, This study investigated the academic performance of students from different secondary schooling systems in an environmental studies course. Questionnaire survey data and the assessment results of a compulsory course of the students were used for this study. Results indicated significant differences in academic performance in the environmental studies course between three different groups of students. The students that completed a threeyear senior secondary education outperformed their counterparts who completed the pre-associate degree and four-year senior secondary education in the environmental course assessment results. Students' environmental attitudes were positively correlated with academic performance on the environmental course, suggesting that students with better environmental attitudes performed better in the environmental studies course.

2. Naima M Gumaga-Pendi, (Nov 6, 2019) Academic Achievement in Science of MSU Maguindanao Students in Relation to Their Science System Admission Scholarship Examination Scores.This research seeks to determine the academic achievement in science of students in the MSU Maguindanao High School Department. Specifically, it aims to assess the performance of the students in science for the last five years, to determine the significant difference in the academic achievement in science between the students of the science curriculum and the Vocational Agriculture curriculum, to find out the students' performance in System Admission Scholarship Examination in Science for the last five years, as well as the significant difference in the performance in the System Admission Scholarship Examination between the students of the science curriculum and the Vocational Agriculture curriculum, and the correlation between academic achievement in science with that of System Admission Scholarship
Examination scores in Science. The students in the Science curriculum have a mean grade of 81.833 indicating fair performance while the students in the Vocational Agriculture Curriculum has a mean grade of 78.66 indicating poor performance. Students who have high grade in their Science subjects tend to have high scores in the SASE in science. There is a significant relationship between the science grades and the SASE scores of the students.

3. ShirinShafieiEbrahim (February 2020) Environmental Sciences Students' Achievements via Conventional and Technology-Based Instructions. This study is about the roles of instruction through technologies on the students' academic performance in Environmental Sciences subject. Totally, 60 sophomore of a Malaysian public university were selected based on convenience sampling. For data collection, students with close pre-test scores were chosen to be in the same group. For data analysis, SPSS assisted to calculate the mean, standard deviation and independent sample ttest. Based on statistical analysis, technology-based instruction affects students' academic achievement positively and they find it more effective in teaching Environmental Sciences compared to conventional approaches. It is highly suggested that teachers put more efforts into teaching by means of technologies to Environmental Science students to help them improve their academic success.

\section{Need for the study}

Our environment is very important to us because it is where we live and share resources with other species. Environmental science enlightens us on how to conserve our environment in the face of increasing human population growth and anthropogenic activities that degrade natural resources and ecosystems. Such highly important field thus requires sufficient and ample awareness among the Environmental Science learning B.Ed., students which in turn inculcate not only the knowledge, besides the basis for sustainable development.

\section{Objectives of the study}

The main objective of this investigation is to study the relationship between male and female, Arts and Science students and Undergraduate and Postgraduates student, in their Academic Achievements in environmental science.

The present study has been designed to achieve the following objectives:

- To study the academic achievement of college students environmental science. 


\section{EPRA International Journal of Research and Development (IJRD)}

- To carry out a comparative study of academic achievements of Arts and Science students.

- To carry out a comparative study of academic achievements of U.G and P.G students.

\section{Hypothesis}

To attain the proceeding objectives, the following hypotheses are proposed:

- There is no significant difference among college student with respect to academic achievement in environmental science.

- There is no significant relationship between academic achievements of Arts and Science students

- There is no significant relationship between academic achievements of U.G and P.G students

\section{Population}

The population of this study included all the undergraduate and postgraduate students of B.Ed. Students from different college of Pondicherry region.

\section{METHODOLOGY}

Stratified random sampling technique was used to collect data from the population.

\section{Tools used}

science

Academic achievement in environmental

\section{Statistical techniques used}

The following statistical techniques are used for the studies

Mode.

1. Descriptive Analysis- Mean, Median and

2. Standard Deviation

3. T-test

\section{Analysis and interpretation of data}

The data collected were analyzes using appropriate devices like mean, median and mode

From the calculated value hypothesis were tested and the level of significance were found. Then the calculated values were subjected to interpretation.

Hypothesis -I

There is no significant difference among college student with respect to academic achievement in environmental science

\begin{tabular}{|c|c|c|c|c|}
\hline $\begin{array}{c}\text { Sl.no } \\
\text { Academic } \\
\text { achievement }\end{array}$ & 150 & Mean value & Median value & Mode value \\
\hline
\end{tabular}

The academic achievement mean value is 39.08. It is greater than the standard norms value. Hence hypothesis is rejected. The academic achievement in environmental science of the total sample is high.

Hypothesis -II

There is no significant relationship between academic achievements of Arts and Science students

\begin{tabular}{|l|l|l|l|l|c|}
\hline Sl.no & Gender & N & Mean value & Std.Deviation & Std.ErrorMean \\
\hline 1 & Art & 75 & 36.44 & 2.8 & 6.8 \\
\cline { 1 - 5 } & Science & 75 & 41.98 & 3.9 & \\
\hline
\end{tabular}

The calculated value is more than the table value at $0.05 \%$ level of significance; therefore the null hypothesis is rejected.

\section{Hypothesis III}

There is no significant relationship between academic achievements of U.G and P.G students

\begin{tabular}{|c|c|c|c|c|c|}
\hline Sl.no & Gender & N & Mean value & Std.Deviation & $\begin{array}{c}\text { Std. } \\
\text { ErrorMean }\end{array}$ \\
\hline 1 & UG & 75 & 38.8 & 4.14 & 0.21 \\
\hline 2 & PG & 75 & 39 & 3.99 & \\
\hline
\end{tabular}




\section{EPRA International Journal of Research and Development (IJRD)}

The calculated value is more than the table value at $0.05 \%$ level of significance; therefore the null hypothesis is rejected.

\section{CONCLUSION}

Man is a social animal. Without Environment there is no Society. In order to achieve sustainable development, each and every one should be aware of the environment, the B.Ed., students not be spared. From the study the Research scholar has found out that the knowledge of Environmental Science prevails much better among the Science students compared to Arts students. It is also found that the knowledge of Environmental Science prevails much among the Post Graduate students when compared to Under Graduate students.

\section{REFERENCE}

1. Andrews, K. E., Tressler, K. D., \&Mintzes, J. J. (2008). Assessing environmental understanding: An application of the concept mapping strategy.
Environmental Education Research, 14(5), 519536. doi: 10.1080/13504620802278829 [Taylor \& Francis Online], [Web of Science ®], [Google Scholar]

2. Arcury, T. A. (1990). Environmental attitude and environmental knowledge.Human organization, 49(4), 300-304. [Crossref], [Web of Science ®], [Google Scholar]

3. Lewis Ting On Cheung, Lincoln Fok\& Gloria Rui Gou (2016) Students' academic performance in environmental studies: an empirical study of different groups of secondary school graduates, International Research in Geographical and Environmental Education, 25:3, 211-225, DOI: 4.

4. Gumaga-Pendi, Naima M, Academic Achievement in Science of MSU - Maguindanao Students in Relation to Their Science System Admission Scholarship Examination Scores (August 14, 2018). Proceedings of the International Conference on Responsive Education \& Socio-Economic Transformation (ICRESET) 2018, Available at SSRN: 